\title{
Unfreezing Credit Markets
}

\section{Citation}

Lucian Bebchuk, Unfreezing Credit Markets (Harv. John M. Olin Discussion Paper Series No. 622, Dec. 2008).

\section{Permanent link}

http://nrs.harvard.edu/urn-3:HUL.InstRepos:26194805

\section{Terms of Use}

This article was downloaded from Harvard University's DASH repository, and is made available under the terms and conditions applicable to Other Posted Material, as set forth at http:// nrs.harvard.edu/urn-3:HUL.InstRepos:dash.current.terms-of-use\#LAA

\section{Share Your Story}

The Harvard community has made this article openly available.

Please share how this access benefits you. Submit a story.

Accessibility 
ISSN 1936-5349 (print)

ISSN 1936-5357 (online)

\section{HARVARD}

JOHN M. OLIN CENTER FOR LAW, ECONOMICS, AND BUSINESS

\section{UNFREEZING CREDIT MARKETS}

Lucian A. Bebchuk

Discussion Paper No. 622

$12 / 2008$

Harvard Law School

Cambridge, MA 02138

This paper can be downloaded without charge from:

The Harvard John M. Olin Discussion Paper Series:

http://www.law.harvard.edu/programs/olin_center/

The Social Science Research Network Electronic Paper Collection:

This paper is also a discussion paper of the

John M. Olin Center's Program on Corporate Governance. 
December 2008

\section{Unfreezing Credit Markets}

\section{Lucian Bebchuk $^{\curlyvee}$}

Despite the large infusion of capital into the financial sector and low interest rates, the flow of financing to operating firms has failed to return to normal levels. One explanation suggested is that banks still lack confidence because they need time to adjust to the new environment. Another is that the reduced flow of credit reflects banks' rational assessment of borrowers' bleak prospects in the current economic conditions. This paper puts forward a third explanation. When the prospects of operating firms are interdependent, banks' decisions on whether to lend to a given operating firm depend on their expectations about whether other operating firms will receive financing. As a result, an inefficient credit market freeze may arise in which banks avoid lending to operating firms due to their self-fulfilling expectations that other banks will not be lending. Such an inefficient freeze may persist even when banks have ample capital and interest rates are brought down to a barely positive level.

Facing an inefficient and persistent credit freeze, I argue, the government should consider getting the economy out of it by taking upon itself the credit risks involved in providing a substantial amount of new lending to operating firms. This can be accomplished by (i) providing banks with non-recourse financing for portfolios of new loans to operating firms, or otherwise agreeing to bear part of the risks generated by such portfolios, in return for a share of the upside, or (ii) setting up government-funded, privately managed funds dedicated to making such loans. These mechanisms funds can contribute substantially, both directly and indirectly, to producing a credit thaw.

Key words: Credit freeze, credit crunch, credit thaw, financial crisis, self-fulfilling crisis, banks, financial institutions, run on the bank, coordination failure.

JEL Classification: D21, E44, E50, E58, E62, G18, G21, G28, H50, P11.

$\diamond$ William J. Friedman and Alicia Townsend Friedman Professor of Law, Economics, and Finance, Harvard Law School; and Research Associate, National Bureau of Economic Research. I am grateful to David Levine and Yaron Nili for helpful research assistance and to Rafael Eldor, Allen Ferrell, and Howell Jackson for valuable discussions. For financial support, I am grateful to the John M. Olin Center for Law, Economics, and Business.

A model for studying credit freezes and alternative government responses to them is developed in "Self-fulfilling Credit Market Freezes," Harvard John M. Olin Center Discussion Paper No. 623 (2008), co-authored with Itay Goldstein and available at http://www.law.harvard.edu/faculty/bebchuk. 
"Don’t panic about the stock market. Panic about the credit markets instead. Interest rate on 3-month Treasuries at $0.02 \%$; interest rate on high-yield (junk) bonds over $20 \%$. This is an economic emergency."

- Paul Krugman, November 20, $2008^{1}$

\section{INTRODUCTION}

One of the important dimensions of the deep economic crisis of 2008 has been the credit crunch - the drying up of credit extended by financial institutions to "Main Street" operating (nonfinancial) firms. As of the end of November 2008, borrowing by operating firms remained abnormally costly and difficult, with the spreads between corporate bond yields and government bonds at abnormally high levels. ${ }^{2}$ During the three-month period of August through October 2008, new loans to large borrowers were less than half their level in the corresponding period in the preceding year. ${ }^{3}$

A major aim of the legislation adopted by Congress and the Treasury's use of the capital authorized by it has been to "get lending going again to support the American people and businesses" ${ }^{4}$ and to "increase the flow of financing to U.S. businesses and consumers." ${ }^{5}$ But even after the government's infusion of large amounts of additional capital into the financial sector, the credit crunch appears to persist. ${ }^{6}$

The credit crunch has been viewed earlier as a consequence of the capital losses suffered by banks due to the housing market correction. ${ }^{7}$ But why does credit flow fail to return to normal levels despite the infusion of so much additional capital into the financial sector? The Treasury Department has argued that credit flow to operating firms has not yet returned to normal levels because banks still lack confidence; in this view, all we need to do is wait until banks regain their confidence for lending to return to normal

${ }^{1}$ Blog post, Conscience of a Liberal, at www.krugman.blogs.nytimes.com/.

2 General Accountability Office, Troubled Asset Relief Program: Additional Actions Needed to Better Ensure Integrity, Accountability, and Transparency, December 2008, at 51-54.

3 David Scharfstein and Victoria Ivashina, Bank Lending during the Financial Crisis of 2008, Working Paper, Harvard Business School.

${ }^{4}$ Testimony of U.S. Treasury Secretary Henry Paulson before the House Financial Services Committee, Nov. 18, 2008.

${ }^{5}$ General Accountability Office, supra note _, at p. 7.

${ }^{6}$ In testimony before the Financial Services Committee, November 18, 10082, Chairman Bernanke indicated that "credit conditions are still far from normal, with risk spreads remaining very elevated and banks reporting that they continued to tighten lending standards," and that there has been "little or no bond issuance by lower-rated corporations or securitizations of consumer loans in recent weeks.”

${ }^{7}$ General Accountability Office, supra note _, at 11. 
levels. ${ }^{8}$ The chair of the congressional oversight panel in turn suggested that decreased lending reflects banks' rational assessment of borrowers' bleak prospects in today's environment; in this view, there is again nothing the government should do directly with respect to the flow of financing; it will resume only when the economy's fundamentals improve, and the government should focus on improving them. ${ }^{9}$

This paper develops a third explanation that has thus far received insufficient attention: a continuing credit freeze might be due to banks' rational and self-fulfilling expectations that other banks will not be extending loans to operating firms. And to the extent that the current credit crunch is at least partly due to this explanation, the government might have an important and direct role to play in unfreezing the credit freeze.

In a modern economy, the prospects of operating firms are likely to be interdependent; an operating firm's success (and ability to repay loans) will depend on whether other operating firms obtain financing. Operating firms commonly obtain their inputs from other firms, and often sell their output to other firms or their employees.

Consider a bank choosing whether to lend to operating firms or park its capital in treasuries. Suppose that lending to any given operating firm will generate an expected return of $10 \%$ if other operating firms obtain financing, but produce an expected loss of $5 \%$ if they do not. In this case, the economy might get stuck in an inefficient credit freeze in which banks believe other banks are likely to avoid lending and, given these expectations, rationally choose to park their own capital in treasuries to avoid the expected 5\% loss from lending when other banks don’t lend.

The problem is similar to the familiar "run on the bank" problem. In a run on the bank, depositors produce a collectively inferior outcome by electing to withdraw their deposits out of self-fulfilling fears that other depositors will withdraw. In an inefficient credit market freeze, the problem is similarly due to "coordination failure." Here, however, financial institutions are not the target of runs; rather, they rationally run away from operating firms.

What can be done to get an economy out of an efficient credit market freeze? Interest rate cuts and an infusion of capital into the banking sector can help, because they narrow the range of circumstances in which an inefficient credit freeze may arise. But their ability to eliminate an inefficient credit freeze equilibrium is limited. As long as lending to an operating firm will not yield a positive expected return if other operating firms fail to obtain credit - which may be the case when macroeconomic fundamentals are unfavorable - a credit freeze may persist even when banks are well capitalized and interest rates set by the Federal Reserve are barely positive. In the example above, banks

${ }^{8}$ Interim Assistant Secretary for Financial Stability Neel Kashkari remarked on December 5 that "we are still at a point of low confidence ... While confidence is low, banks will remain cautious about extending credit ... As confidence returns, we expect to see more credit extended.

9 See Diana Henriques, Bailout Monitor Sees Lack of a Coherent Plan, NYTimes, December 2, 2008 (the chair of the Congressional oversight panel for the Economic Stabilization Act of 2008 expresses concerns that banks' not lending is due to "their potential borrowers getting less creditworthy with each passing day.”) 
expecting other banks to avoid lending will prefer doing so as well, even if they have ample capital and the yield on parking their funds in treasuries is hardly positive.

When interest rate cuts and capital infusion into the financial sector fail to eliminate an inefficient credit freeze, is there anything more that the government can do? Yes, the government can go beyond intervening at the level of the financial sector and intervene at the level of lending to operating firms: it can take upon itself some of the credit risks involved in substantial amount of new lending to operating firms.

Although in theory the government could lend directly to operating firms, government officials do not have the ability of private firms to screen firms with good projects that deserve financing from those that do not. Accordingly, the intervention should be designed to harness the private sector's expertise in performing such screening. And I put forward alternative mechanisms for doing so.

Suppose that the government wishes to have at least $\$ 250$ billion of additional financing flow to operating firms. Under one possible mechanism, the government would facilitate banks' putting together a diversified portfolio of newly originated loans. The government would provide non-recourse financing for part of the capital, and agree to have part of any losses to the portfolio borne by the government's capital, in return for a share of the upside. In the example considered above, to induce banks to put together a portfolio of new loans, it would be sufficient for the government to invest $10 \%$ of the needed capital and agree to have any losses to the portfolio (relative to the yield on treasuries) of up to $10 \%$ of the value of the extended loans borne by the government's investment.

What share of the upside should the government demand from banks in return for providing such insurance? This can be determined through a competitive process. Banks could be invited to offer bids indicating the size of the portfolio they wish to put together and what share of the upside they are willing to give the government in return for the insurance provided. The government would then accept the highest offers that will collectively produce additional lending in the desired amount of $\$ 250$ billion.

Under an alternative mechanism, the government would place a total of $\$ 250$ billion in a significant number of funds: say 25 funds with $\$ 10$ billion each. Each fund would be run by a private manager charged with putting together a portfolio of loans. The manager would be compensated with a share of the profits (relative to the yield on treasuries) generated by the fund, and the size of the share could be set through a competitive process after a pool of qualified candidates is established.

Under each of these mechanisms, the party putting together the portfolio of new loans - the bank or the fund's manager-will have incentives to lend only to operating firms with good projects. And the government's taking upon itself credit risks will directly lead to $\$ 250$ billion flowing to operating firms. But the program’s contribution to unfreezing credit markets will not be limited to this direct effect.

The expectation that many operating firms will receive financing as a result of this \$250-billion program will affect what banks do with their own capital-increasing their willingness to lend this capital, which they might otherwise elect to hoard. This 
effect would further contribute to producing a credit thaw. Furthermore, to the extent that the program produces a credit thaw, its costs to the government will be rather limited, because the credit risks the government has taken upon itself will not materialize.

Of course, either one of the mechanisms I put forward raises various questions and choices of implementation and design. I discuss some of them below and flag others. My aim in this paper, however, is not to provide a complete blueprint for implementation. Rather, my aim is to show that direct intervention at the level of lending to operating firms can provide an additional and important tool for getting out of an inefficient credit freeze; to explain its potential benefits; to put forward some basic alternative versions for implementing this approach; and to identify and discuss some of the key questions of institutional design that such implementation would need to answer.

The rest of this paper is organized as follows. Section II describes how an inefficient credit freeze may arise out of banks' rational actions. Section III discusses how interest rate cuts and infusion of capital into banks affect a credit freeze, and explains why such measures might be unable to get the economy out of an inefficient credit freeze. Section IV discusses mechanisms for direct intervention by the government in lending to operating firms. Finally, Section V concludes.

\section{CREDit FreEzeS AS SELF-FulfILLING “RunS”}

I argue in this paper that a credit freeze can result from a coordination failure in which the separate decisions of financial institutions, each making a rational and optimal decision, lead to an outcome that is inferior from their collective perspective. The idea that inefficient equilibria may result from a coordination failure and self-fulfilling expectations has been extensively studied in the context of runs on banks and other financial firms. ${ }^{10}$

In a standard run-on-the bank scenario, depositors will be better off if they all keep their deposits at the bank. And this is what will happen as long as depositors expect other depositors not to run. However, because depositors will be better off withdrawing their deposits in the event that others do so, an inefficient run on the bank may occur. Expectations that depositors will run are self-fulfilling. In a similar fashion, self-fulfilling expectations lead to an inefficient outcome in the analysis below; this time, however, financial institutions are not the target of the run but rather do the running themselves.

${ }^{10}$ The economic modeling of bank runs begins with Douglas W. Diamond and Philip H. Dybvig, Bank runs, deposit insurance, and liquidity, 91 Journal of Political Economy 401-419 (1983). For more recent contributions, see, e.g., James Peck, \& Karl Shell “Equilibrium Bank Runs,” 111 Journal of Political Economy 103-123 (2003); Itay Goldstein and Ady Pauzner, "Demand deposit contracts and the probability of bank runs,” 60 Journal of Finance 1293-1328 (2005). 


\section{A. Lending to Main Street}

To fix ideas, suppose that the economy has $N$ banks, that each bank has an amount of capital $K_{B}$, and that the total amount of capital in the economy's financial sector is thus $K=N_{B}{ }^{*} K_{B}$. The banks can use (any part of) their capital in one of two ways: (i) invest in the economy's riskless asset (say, treasuries), which would provide a return of $I$, or (ii) lend to operating firms.

The economy has a large number of operating firms. These firms have projects that they will be able to finance only if they get loans from the banks. There are two types of operating firms: firms with bad projects that, if funded, will generate a return of zero; and firms with good projects that will produce a positive expected return. Banks have the expertise, which the government does not, to screen operating firms with good projects from those with bad projects, and the discussion below will thus focus on operating firms with good projects.

Each operating firm with a good project needs financing to be able to carry out its project. A bank providing the needed financing will get (factoring in the risk of no or partial recovery) an expected return of $R$. This expected return depends on the state of the economy. The extent to which operating firms can be expected to prosper depends on various macroeconomic fundamentals such as the economy's level of consumer spending, unemployment levels, energy prices, exchange rates, and so forth. Thus, denoting the extent to which macroeconomic fundamentals are favorable by $M$, we can think of $R$ as being a product of $M, R(M)$, with $R$ increasing with $M$.

The expected return from lending to operating firms also depends on $D$, the fraction of the financial sector's total capital $K$ that will be lent to operating firms and thus in turn the number of operating firms (with good projects) that will get financing for and operate their projects. In a modern economy, the prospects of many if not most operating firms are interdependent on other operating firms' ability to obtain financing. A given operating firm, for example, may need other operating firms to provide it with inputs. Furthermore, the operating firm may plan on selling its output to other operating firms or to its employees and their dependents and its sales will thus be hurt if those other firms do not operate. ${ }^{11}$

Specifically, for any given state of macroeconomic fundamentals $M$, let us denote by $R(M)_{H}$ the expected return to a bank from lending to an operating firm if all other banks use their capital to make loans to operating firms, and let us denote by $R(M)_{L}$ the (lower) expected return to the bank from lending to the operating firm if all other banks are going to avoid lending to operating firms. If some banks lend to operating firms and others do not, with a fraction $D$ of the total capital lent to operating firms, the expected return will be the weighted average $D^{*} R(M)_{H}+(1-D)^{*} R(M)_{L}$.

\footnotetext{
${ }^{11}$ For an early work on the interdependence among the economy’s firms, see Russell Cooper and Andrew John, Coordinating coordination failures in Keynesian models, 103 Quarterly Journal of Economics 441-463 (1988).
} 


\section{B. Inefficient Credit Freezes}

Turning to the outcome in the above circumstances, let us begin by identifying the outcome that will be efficient and in the banks' collective interest. If $R(M)_{H}$ exceeds $I$, the banks will be collectively better off if they all lend to operating companies, as they will each capture in this way an expected return of $R(M)_{H}$ which will exceed their alternative return of $I$. In contrast, if macroeconomic fundamentals are sufficiently unfavorable that $R(M)_{H}$ is lower than $I$, the banks will be collectively better off if they all avoid lending to operating firms, as lending will provide each of them with an expected return below the alternative return of $I$.

Now let us consider what outcome will be produced by banks' individually rational decisions. When macroeconomic conditions are sufficiently favorable that even $R(M)_{L}$ exceeds $I$, banks will certainly lend, and the outcome will overlap with the one that is in their collective self-interest. For in this case, each bank will expect to profit from lending regardless of how other banks are expected to act. Also, when macroeconomic fundamentals are so poor that even $R(M)_{H}$ falls below $I$, banks will certainly not lend, and the outcome will again overlap with the one in their collective self-interest. For in this case, a bank's optimal course of action will again not depend on how other banks are expected to act: not lending will be optimal even if other banks elect to lend.

The problem lies in the circumstances in which $R(M)_{H}$ is above $I$ but $R(M)_{L}$ falls below it. In this case, a lending equilibrium will be in the banks' collective interest, but it is not certain to occur-because in this set of circumstances, there are two possible equilibria. There are two possible sets of expectations that banks might form and each one of them will be self-fulfilling.

In the "good" lending equilibrium, banks expect other banks to lend to operating firms, and these expectations are self-fulfilling, leading all banks to lend: given the expectations that other banks will lend, each bank will be better off lending and getting an expected return of $R(M)_{H}$. In the "bad" credit freeze equilibrium, banks expect other banks to avoid lending to operating firms, and these expectations are again self-fulfilling, leading all banks not to lend: given the expectations that other banks will not lend, each bank will be better off not lending and getting $I$ rather than lending and receiving a lower expected return of $R(M)_{L}$. This inefficient credit freeze equilibrium is the focus of our attention.

\section{Will an Inefficient Credit Freeze Occur?}

For an inefficient credit freeze to be possible, the economy's fundamentals must be sufficiently low that $R(M)_{L}$ is below $I$. As we have seen, if fundamentals are so favorable that even $R(M)_{L}$ exceeds $I$, it is optimal for banks to lend regardless of their expectations about how other banks will act.

Suppose, then, that the economy is such that $R(M)_{L}$ falls below $I$ while $R(M)_{H}$ remains above it. It might be suggested that the fact that an inefficient credit freeze is 
rational and possible in these circumstances does not imply that it will happen; there are two possible equilibria and, it might be hoped, banks will always elect to act in a way that will produce the good lending equilibrium.

Unfortunately, in a world in which each bank has to act separately and thus cannot be certain of how other banks will act, there is no basis for believing that banks will generally avoid an inefficient credit freeze equilibrium. For one thing, banks might differ in their estimates of $M$, might well not know what estimates of $M$ other banks have, and might not know what other banks' expectations are about their fellow banks' estimates of $M$. With such uncertainty, banks have to take seriously the possibility that other banks will not lend, and will thus give weight to the cost $\left[I-R(M)_{L}\right]$ that they will have to bear if they lend and other banks avoid lending.

Itay Goldstein and I have developed a model for studying how banks will act in the above circumstances and for identifying the range of circumstances in which an inefficient credit freeze equilibrium will arise. ${ }^{12}$ We use for this purpose the global game methodology developed by economists for identifying a unique equilibrium in games with strategic complementarities that make one agent's payoff depend on other agents' actions. We assume, as is standard in such models, that each bank gets a signal about the value of $M$ and makes a decision based on this signal, as well as taking into account that other banks are making decisions in a similar way based on their own signals of $M$. Our work shows that an inefficient credit freeze can be expected to emerge as the unique equilibrium in a range of circumstances (and also identifies this range).

Finally, it is worth commenting on the effects that depleting the banks' total capital can have on the flow of financing to operating firms. Suppose that the banks lost, say, $40 \%$ of their total capital as a result of investments that performed poorly. The above analysis indicates that the effect of such capital losses will not be limited to the direct effect of making $40 \%$ of the preceding total capital no longer potentially available for operating firms. The capital losses will also have an indirect effect of reducing the willingness of banks to use their remaining capital to extend loans to operating firms. For the capital losses will lower banks' expectations as to the number of operating firms that will receive financing; and, because of the interdependence among operating firms, will also lower the willingness of banks to use their remaining capital for lending to such firms.

\section{THE LiMITS OF INTEREST RATE CUTS AND CAPITAL INFUSIONS}

It is widely belied that the government should generally avoid lending directly to operating firms and leave this job to the financial sector. The underlying premise is that financial institutions have expertise in screening operating firms with good projects from those with bad projects. Thus, to the extent that a credit freeze is inefficient, it is natural

${ }^{12}$ Lucian Bebchuk and Itay Goldstein, Self-Fulfilling Credit Market Freezes, Harvard John M. Olin Center Discussion Paper No. 623 (2008). 
to consider first whether the freeze can be addressed by government intervention at the level of the financial sector.

During the crisis of 2008, the government has made substantial use of two measures: (i) interest rate cuts, and (ii) direct infusion of capital into banks. Both measures can sometimes - but, importantly, not always - get the economy out of a credit freeze. As explained below, these measures cannot be relied on to eliminate a credit freeze because such a freeze may arise and persist even if the economy's interest rate is barely positive and banks have ample capital.

\section{A. Interest Rate Cuts}

Under normal market conditions, interest rate cuts are the most important instrument for increasing bank lending. And governments have made massive use of this commonly powerful weapon during the economic crisis of 2008. The Federal Reserve Board reduced the U.S. interest rate from 4.25\% in January 2008 to $1 \%$ in October 2008 and is expected to lower it again soon (with little room left to go further...). Many central banks around the world have similarly made large cuts in interest rates. ${ }^{13}$

In some circumstances, an interest rate cut can get the economy out of an inefficient credit freeze. Suppose that the economy is in such a freeze, and that $R(M)_{L}$ is below the current interest rate $I$ (as is necessary for such an equilibrium) but above zero. In this case, a cut in interest rates that would bring the interest rate to somewhere between 0 and $R(M)_{L}$ would surely eliminate the inefficient credit freeze. For once the lower interest rate is set, each bank will be better off lending even if other banks will not lend, and each banks will thus prefer to lend regardless of its expectation as to what other banks will do.

Suppose, however, that $R(M)_{L}$ is negative - that is, assuming other banks are not going to lend, a bank will expect lending to a given operating firm to yield a negative return. In this case, if other banks are expected not to lend, each bank will be better off parking its capital in government bonds, even if the yield on them is barely positive, rather than lend to operating firms. In these circumstances, an interest rate cut cannot be relied on to eliminate an inefficient credit freeze, which would remain self-sustaining.

\section{B. Infusion of Capital to the Banking System}

Earlier in the current crisis, the credit crunch was attributed to a deterioration in financial firms' capital positions. Seeking to restore stability to the financial sector and to increase the flow of credit to operating firms, governments around the world arranged for financial firms to receive large amounts of additional capital. In October 2008, in conjunction with similar actions by the U.K. and other major European countries, and coordinated actions by the Federal Reserve and the FDIC, the U.S. Treasury announced plans to allocate $\$ 250$ billion to purchase senior preferred shares in a broad array of

${ }^{13}$ In October 2008, facing a worldwide contraction in lending, -21 countries around the world, including the U.S., simultaneously cut interest rates. 
financial institutions and, as of this date, most of these funds have already been invested. $^{14}$

Infusion of capital into banks can reverse a reduction in the flow of credit brought about by preceding losses in banks' capital. As explained earlier, such capital losses may decrease the flow of credit in two ways: directly, because the lost capital will no longer be potentially available; and, indirectly, by making banks more reluctant to lend capital they still have because of their lowered expectations as to the number of operating firms that will receive financing. Accordingly, capital infusion into banks may facilitate lending in two ways: directly, by adding additional capital that potentially will be available for operating firms to borrow; and, indirectly, by increasing the number of operating firms expected to receive financing - thereby potentially increasing banks’ willingness to lend the capital they had prior to the infusion.

Although capital infusion may undo a credit freeze brought about by preceding capital losses to the banking sector, it cannot be relied on to eliminate any inefficient credit freeze. When macroeconomic fundamentals are unfavorable, a credit freeze might arise even when the banks have ample capital. To see this, suppose that banks initially lost $40 \%$ of their total capital and that the government arranged for a capital infusion that brought their total capital back to $K$. Even with $K$ in the banks' coffers, the banks may continue to avoid lending to operating firms as long as $R(M)_{L}$ remains below $I$. For in this case, even though they have ample capital to lend, banks' expectations that other banks will not lend will remain self-fulfilling.

The infusion of capital into banks during the economic crisis has been successful in preventing runs by depositors and other creditors on financial institutions. But creditor freezes involve a different type of coordination failure than a creditor run on a financial institution - a failure of coordination not among financial firms' creditors, but among financial institutions themselves. As long as $R(M)_{L}$ remains below $I$, the existence of ample capital in the hands of the banking sector cannot be relied on to eliminate inefficient credit freezes.

\section{DIRECT INTERVENTION IN LENDING TO OPERATING FIRMS}

The analysis thus far has highlighted the limits that interventions at the level of the financial sector - interest rate cuts and capital infusions - have in unfreezing credit markets. What else could be done? In such circumstances, an approach that the govern-

14 In addition, the FDIC announced that it would temporarily guarantee the senior debt of all FDIC-insured institutions, thus lowering their borrowing costs, and the Federal Reserve Board extended (as of November 21, 2008) almost $\$ 900$ billion in loans to financial institutions, including through the purchase of large amounts of their commercial paper. The Fed established the Commercial Paper Funding Facility in October 2008, and it purchased during the subsequent several weeks hundreds of billions of dollars worth of commercial paper from financial intermediaries such as Morgan Stanley, GMAC, and American Express. 
ment can use to produce a credit thaw is intervention at the level of the market for lending to operating firms.

\section{A. The Approach}

The general approach put forward in this section (and I will discuss below two versions of a mechanism for implementing it) is for the government to take upon itself directly risks involved in lending to operating firms. The measures discussed in the preceding section - interest rate cuts and capital infusion - provide banks with ample capital for lending, and reduce the attractiveness of not lending, but they do leave banks with the need to bear fully the risks involved in the loans, if any, that they extend to operating firms. In an inefficient credit freeze, banks elect to avoid bearing such risksand they do so rationally, given their expectations that other banks will do the same- - but this produces an inefficient outcome. To break through this coordination failure and resume the flow of credit, the government can take upon itself all or some of the risks involved in a substantial amount of new lending to operating firms. Doing so will: (i) first and directly, provide operating firms with new financing whose risks the government will agree to bear, fully or partly, and (ii) indirectly, but importantly, encourage additional lending by banks, induced by higher expectations as to the number of operating firms that will receive financing.

It would be best to assess the usefulness of this approach by considering concrete mechanisms for its implementation. One straightforward version, but one that should not be favored for reasons to be presently discussed, would have the government lend directly to operating firms. It is worth noting that the Federal Reserve recently established a special-purpose vehicle for purchasing highly rated commercial paper, and it allowed access to it not only to financial firms but also to operating firms that are highly rated (though it is not known which operating firms if any have thus far used this facility). It should be stressed, however, that this funding has been limited to the most highly rated borrowers and, even for them, only to short-term (up to three month) loans.

A substantial program of direct lending by the government to operating firms would be problematic because government officials do not have private parties' ability to screen operating firms with good projects (and thus good repayment prospects) from operating firms with bad projects (and thus poor repayment prospects). The Fed's commercial paper operations are premised on the assumption that, when a firm is highly rated and the loan is for no more than three months, the government can attach a very high probability to the firm's being able to repay. Operating firms, however, come in different stripes, large and small, highly rated and unrated, and they may need not only short-term credit but also loans for longer periods, depending on when financed projects are expected to bear fruit. Thus, to respond to the varied credit needs of operating firms in the economy, a program of direct lending would require careful study and screening of potential borrowers, which the government would not be well suited to do. 
For this reason, the approach put forward in this section would be best implemented in ways that harness the ability and expertise of private parties, appropriately incentivized, to study and screen potential borrowers. Unlocking credit freezes should not lead to credit flowing to all operating firms - only to those operating firms with good projects. Below I discuss two mechanisms for doing so; after explaining how they would operate, I will explain their benefits (as well as the benefits of the approach they would implement); in particular, I will discuss how they will directly ensure that substantial additional capital will flow to operating firms, and only to firms that have good projects; how this effect will be reinforced by their indirectly inducing banks to provide even more lending to operating firms using the banks' own capital; and why the costs to taxpayers of using this approach to produce a credit thaw would likely be quite limited.

\section{A. Providing Banks with Partial Insurance against Losses on Portfolios of New Loans}

The first mechanism to be discussed would aim at inducing banks to originate new loans to operating firms. Under this mechanism, the government would enter into arrangements with banks under which it would bear some of the risks generated by a portfolio of new loans put together by the bank in return for a share of the upside produced by this portfolio.

Suppose that the government wishes to get at least $\$ 200$ billion of additional lending to operating firms. And suppose that, as in the example used in the introduction, lending to any given operating firm will generate an expected return of $10 \%$ if other operating firms will obtain financing, but produce an expected loss of $5 \%$ if they will not. Suppose further that the yield on treasuries is $1 \%$. In this case, to induce a bank to put together a portfolio of new loans, it would be clearly sufficient for the government to agree to bear any losses produced by the portfolio of up to $10 \%$ of the amount extended in loans.

One way to produce this allocation of risk is for the government to provide $10 \%$ of the capital needed for extending the loans as non-recourse financing that will be repaid only from the portfolio's payoffs. Furthermore, this financing will have the lowest priority and be paid only after the bank's initial investment in the portfolio is fully recouped. An alternative way to produce this allocation would be for the government to simply "insure" the bank against losses of up to $10 \%$ of the investment in the portfolio, without any upfront capital provision, in return for a share of the upside on the portfolio.

The portfolios underwritten under this program will have to be diversified. To this end, no single borrower (or a group of related borrowers) will be permitted to constitute more than a specified percentage (say, $3 \%$ or $5 \%$ of the portfolio). Furthermore, the government may consider having some of the portfolios that it underwrites focus on a subset of operating firms, defined by size or industry. With any such broad set, however, the bank will have discretion to choose among potential borrowers. This discretion will be subject only to conflict of interest limitations; banks will not be permitted to place in 
the portfolio underwritten by the government any new loans to a firm to which the bank has already extended loans from its own capital.

An important question is, of course, the share of the upside that the government will demand in return for the provided non-recourse junior financing or insurance. One natural approach would be to use a competitive process. Banks could be invited to offer bids that indicate (i) the size of the portfolio they wish to put together, and (ii) what share of the upside they are willing to give the government in return for the risks taken by it. The government would then accept the highest offers that will collectively produce additional lending in the desired amount of \$200 billion.

The discussion above assumed that the government would assume a horizontal and most risky "tranche" of the risks involved in the new lending, assuming for concreteness that the government would be the bearer of the first $10 \%$ of losses. But one could also consider different cuts. For example, the government could take a "vertical" slice of the risks, agreeing to bear, say, 50\% of the losses, if any, generated by the portfolio. This could be accomplished by the government's providing $50 \%$ of the investment in the portfolio as no-recourse financing and agreeing to have losses to the portfolio borne equally by the capital invested by the government and the capital invested by the bank.

The mechanism is clearly flexible and allows for many variations. If the initial share of downside risks that the government offers to underwrite does not seem to attract sufficient interest from banks, the government's program can be adjusted. As long as a competitive process determines the allocation among banks of non-recourse financing or insurance guarantees, as well as the share of upside the government will get, the program will not involve the government's providing benefits to banks beyond those necessary to induce the desired amount of additional lending.

\section{B. Government-funded, Privately-managed Funds}

Under the second mechanism I would like to discuss, ${ }^{15}$ the government will place a substantial amount of capital in a significant number of government-funded but privately-managed funds dedicated to the purpose of making new loans to operating firms. Continuing to assume that the government seeks to ensure the provision of $\$ 200$ billion in new loans to operating firms, the government will place capital in this amount in, say, 40 funds, each capitalized with $\$ 5$ billion.

Each fund will be managed by a private manager, and it will be important to set the manager's compensation so as to provide desirable incentives. Each manager should receive a reimbursement of expenses - essentially, the expenses of processing loans and managing them will be charged to the fund and not the manager - and should be promised a share of the profits generated by the fund: say, $5 \%$ of the fund's profit (above the yield on treasuries). Like hedge-fund managers under standard arrangements, the

${ }^{15}$ This mechanism is similar to the one I proposed earlier for the government's planned purchase of troubled assets. See Bebchuk, "A Better Plan for Addressing the Financial Crisis," 5 The Economists’ Voice, Issue 5, Article 6 (2008). 
manager will capture a share of the profits but will not have to bear losses should they occur (though more on this below).

The managers will be required not to lend to a single borrower (or group of related borrowers) more than a certain fraction (say, 3\% or 5\%) of the total amount that they will lend. Like other lenders in the marketplace, funds managed by different managers will be able to form a syndicate and provide an operating firm with a larger loan than any one of them would be able to do alone. And one could again consider limiting all or some of the funds to lending to operating firms within a certain subset, defined by size or industry, provided that the manager will have the discretion to make choices within this set of firms.

Monies that the manager has not yet lent to firms will be invested in treasuries. Alternatively, the monies could be kept in the hands of the government and transferred to the manager (until the $\$ 5$ billion limit is reached) as loans are made by the manager. Because the manager will be able to make a profit only by making loans to operating firms, the manager will have an incentive to spend the full \$5 billion on making such loans.

While each fund managers will have an incentive to lend the full \$5 billion to operating firms within the time frame specified by the government, ${ }^{16}$ it is critical to recognize that the fund managers will hardly engage in indiscriminate lending. The managers' profit share will give each manager powerful incentives to screen borrowers and to allocate funds to those borrowers that offer the highest expected return (factoring both the interest rate they are willing to pay and the probability of default). Thus, while government-capitalized, the funds will benefit from the ability of private parties, appropriately incentivized, to screen among operating firms.

How will the profit share of funds managers be set? One option would be to use competitive bidding. After a pool of candidates passing threshold conditions in terms of expertise and otherwise is chosen, the final selection could be based on a bidding process in which candidates bid the profit percentage for which they would be willing to manage a fund.

There is also the issue of conflicts of interest. Funds managers will be chosen among firms and agents with expertise in lending to operating firms, including not only traditional banks, but also other financial institutions and money managers, as well as individuals working for them. To the extent that managers are allowed or expected to engage in other activities during the period they manage a government fund, they should

16 There might be a concern that, if managers are free to wait and make loans later on, they might avoid loans initially, taking part in the credit freeze rather than facilitating a credit thaw. For this reason, managers could be given a time period after which they can no longer make loans. To avoid the distortions that might arise when a deadline induces a manager to allocate at once a very large fraction of the $\$ 5$, a schedule might set what fraction of the total $\$ 5$ billion is expected to be used by different times and "take away" the authority to lend funds not allocated in accordance with the set schedule. 
be precluded from lending to any operating firm in which they have an interest (including, of course, as a creditor).

Finally, one could consider not insulating fund managers completely from the downside of the loan portfolio they select. To be sure, when the portfolio is selected, the manager's profit share, even without any exposure to the downside, will provide a powerful incentive to select the borrowers offering the highest expected return. But one might be concerned that, if a point is reached later on that the loan portfolio declines significantly in value, the manager will no longer have an incentive to do a good job. To the extent that this is a significant concern, one could require a selected manager to bear a very small part of the downside. For example, assuming the managers are promised a $5 \%$ profit share, they could also be required to get a small haircut in the event of losses: say, $1 \%$ of any losses. This could be done, for example, by requiring managers to provide their own capital to finance $1 \%$, or $\$ 50$ million, of the capital of the fund run by the manager. It is important to keep the manager's share of the downside substantially below the manager's profit share to provide the manager with incentives to lend despite conditions that incline banks not to lend. (A manager bearing 5\% of both the upside and the downside would have the same incentives as banks do when investing their own capital.) We do not have to worry, however, that requiring such a haircut would lead to capital being locked in funds that avoid lending. Managers will undertake to manage a fund only if they expect to make loans (otherwise there will be no way to profit) and thus only if the fee schedule offered (say, $5 \%$ of the upside and 1\% of the downside) is viewed by the manager as sufficiently asymmetric to induce lending.

\section{Benefits}

The considered mechanisms will help restore the flow of credit to operating firms both directly and indirectly. Let us begin with the direct effect: each of the two mechanisms will ensure that the desired amount of additional new lending, which we assumed for concreteness is $\$ 200$ billion, will be provided to operating firms, and that informed and incentivized private actors will allocate this funding among operating firms, screening firms with good projects from those without such projects.

In this respect, it should be stressed that the mechanisms' direct financing effect would be more certain than, say, infusing $\$ 200$ billion into banks as additional capital. The capital provided to banks might get "stuck" in their hands, waiting to be deployed in sunnier times, and thus might not make its way to operating firms within the desired time frame. In contrast, the design of the proposed mechanisms ensures that the $\$ 200$ billion will get to operating firms with good projects within the time frame specified by the government.

Because each of the proposed mechanisms can ensure that the desired \$200 billion will reach operating firms before too long, they will also be more effective in encouraging banks to lend the capital they already have than would, say, providing banks with a capital infusion of $\$ 200$ billion. As discussed earlier, banks' expectations as to how 
many operating firms will receive financing affects their decisions whether to lend to any given operating firm. The proposed mechanism will have a more certain effect on these critical expectations that will a cash infusion of $\$ 200$ billion into the banks.

That the proposed mechanisms will contribute more to producing a credit thaw than would providing banks with $\$ 200$ billion in additional capital does not imply that the government's earlier infusion of $\$ 250$ billion into banks would have been better invested in the considered mechanisms. The recent injection of $\$ 250$ billion into banks was aimed not only at increasing the flow of credit to operating firms but also at restoring stability to the financial system and preventing runs on financial firms. And the capital injection appears to have been successful on this second dimension. The point I am making is only that, having restored stability to the banking sector, we should now focus on increasing the flow of credit to operating firms and the proposed mechanisms may offer a more effective tool than additional capital infusions.

Finally, having discussed above the potential benefits of the program, I would like to comment on its costs. To the extent that the program will be successful in producing a credit thaw, its costs could well turn out to be quite limited: in such a case, lending to operating firms that can benefit from the government's program will facilitate adequate returns. As a result, the government's taking of credit risks will produce a credit thaw, but will not impose losses on the government.

\section{CONCLUSION}

Despite the infusion of large amounts of capital to the financial sector and the steep decline in interest rates, the flow of credit to operating firms has not yet returned to normal levels. One explanation given is that banks need time to adjust to the new environment and in the meantime lack sufficient confidence to resume extending credit at normal levels. Another explanation given is that the current low levels of credit extension reflect the banks' pessimistic but informed and rational assessment of borrowers' prospects, given current economic conditions. Both explanations suggest that the government should take no further action at this stage with respect to the credit crunch.

This paper puts forward a third explanation — one that provides an important role for immediate government action. When the prospects of operating firms are interdependent, banks' decisions whether to lend to a given operating firm may well depend not only on an assessment of the value of that firm's project but also on their expectations as to whether other banks will be lending. As a result, a credit freeze equilibrium may arise in which banks avoid lending to large sets of operating firms due to their self-fulfilling expectations that other banks will be doing the same. Furthermore, interest rate cuts and infusions of capital into banks may be unable to get the economy out of such an inefficient credit freeze, which may persist even when interest rates are low and banks have ample capital.

Facing an inefficient but persistent credit freeze, I argue, the government should consider taking upon itself the risk involved in substantial amounts of new lending to 
operating firms. This can be accomplished by setting up government funds dedicated to making such loans and managed by private agents with strong incentives to allocate funds to operating firms with good projects. Alternatively, or in addition, this could be done through insuring some or all of the risks involved in a portfolio of new loans to operating firms put together by a bank. Both mechanisms can contribute significantly, both directly and indirectly, to producing a credit thaw.

To the extent that the current difficulties of operating firms seeking to obtain credit are at least partly due to an inefficient credit freeze, dealing with this freeze is, to use Krugman's words, an economic emergency. The possibility of an inefficient credit freeze, and an examination of the best ways to undo it, are issues that deserve the government's serious consideration. 